\section{Clonally Propagated and Seed-derived Papaya Orchards: II. Yield Comparison}

\author{
Maureen M.M. Fitch ${ }^{1}$ and Paul H. Moore \\ Pacific Basin Agricultural Research Center, Aiea, HI 96701
}

\author{
Terryl C.W. Leong, Leslie Ann Y. Akashi, Aileen K.F. Yeh, \\ Susan A. White, Amy S. Dela Cruz, and Lance T. Santo \\ Hawaii Agriculture Research Center, Aiea, HI 96701
}

\author{
Stephen A. Ferreira \\ College of Tropical Agriculture and Human Resources, University of Hawaii, \\ Honolulu, HI 96822
}

\section{Leslie J. Poland \\ DuPont Agriculture and Nutrition, Waialua, HI 96791}

\begin{abstract}
Additional index words. Carica papaya L., hermaphrodites, micropropagation, rooted cuttings,
\end{abstract} virus resistant papaya

\begin{abstract}
Gynodioecious papaya (Carica papaya L.) seedlings in commercial cropping systems in Hawaii are typically multiple-planted and thinned upon flowering to a single hermaphrodite because seedlings segregate for sex expression. Use of clonally propagated hermaphrodites would eliminate the over-planting practice and may provide other advantages. Yields of clonally propagated hermaphrodites were compared with single- and multiple-planted seedlings in three fields on two islands in Hawaii. Cloned hermaphrodites were either rooted cuttings or in vitro micropropagated plants. Clonally propagated plants bore ripe fruit 1 to 3 months earlier than thinned seedlings and had significantly higher early and cumulative yields. At each site, cumulative yields of thinned seedlings never reached the same level as those of clonally propagated plants. The yield benefit from clonally propagated plants was greatest at Keaau, the lowest sunlight and least productive test site.
\end{abstract}

Hermaphrodite papayas (Caricapapaya L.) are important in commercial papaya production in many tropical and subtropical regions of the world. Germinating seed from self-fertilized hermaphrodites segregate two hermaphrodites to one female(Storey, 1953). The sex of vegetative seedlings is indistinguishable except by DNA analysis such as the polymerase chain reaction (PCR) testing for hermaphrodite-specific DNA bands (Deputy et al., 2002). Therefore, commercial growers typically transplant at least five seedlings per planting hole to have a good probability of having at least one hermaphrodite tree standing for orchard production. The multiple-planted seedlings compete for nutrients and sunlight until flowering 3 to 4 months after transplanting at which time females and extra hermaphrodites are removed.

Cropping systems using hermaphrodite plants would eliminate multiple-planting and the competition and thinning associated with this practice. Fields can be established with clonally propagated rooted cuttings (Allan, 1964, 1993) or micropropagated plants (Chan and Teo, 2002; Drew, 1988; Drew and Vogler, 1993; Fitch et al., 2005). Growth of micropropagated 'Rainbow' papayas (Manshardt, 1998) was compared to rooted cuttings, single

Received for publication 1 Jan. 2005. Accepted for publication 20 Mar. 2005. This research was funded in part by a University of Hawaii College of Tropical Agriculture and Human Resources Minor Crops Special Funds Grant. We thank C. and D. Gonsalves for help in planting.

${ }^{1}$ Corresponding author; e-mail mfitch@pbarc.ars. usda.gov. hermaphrodite seedlings, and thinned seedlings in three locations in Hawaii (Fitch et al., 2005). That study corroborated those of Allan (1964), Chan and Teo (2002), Drew (1988), and Drew and Vogler (1993) by showing that rooted cuttings and micropropagated plants flowered earlier and lower on the trunk compared to seedlings. Micropropagated papayas and rooted cuttings were also shorter in stature compared to seedlings. The question remaining to be answered is: what is the effect of the different ways of establishing the papaya crop on fruit yield? We address this question with this report on papaya fruit yield and its characteristics at the three locations in Hawaii.

\section{Materials and Methods}

\section{Plant materials}

All experiments were conducted with the papayaringspotvirus (PRSV) resistant commercial papaya hybrid 'Rainbow.' 'Rainbow' seeds were gifts of Richard Manshardt, University of Hawaii. Methods involved in the production of in vitro-grown micropropagated plants, cuttings rooted in the greenhouse, PCR-identified hermaphrodite seedlings, and multiple-planted, thinned seedlings used for the experiment were described previously (Fitch et al., 2005).

\section{Field sites}

Keaau. The first established and most extensive test was at Keaau on the island of Hawaii. The test was installed on 30 Apr. 1998 in Papai, an extremely stony soil (USDA, 1972; 1973) withina 750- to 1500-year-old lavaflow(USGS,
1996) at an elevation of $60 \mathrm{~m}$. The average daily temperature was $28^{\circ} \mathrm{C}$ in summer and $23^{\circ} \mathrm{C}$ in winter with a soil temperature range of 22 to 23 ${ }^{\circ} \mathrm{C}$. Rainfall at this site averages $380 \mathrm{~cm}$ annually (USDA, 1973). No additional irrigation is provided. The 30-year(1932-75) solar radiation average from weather stations in Keaau ranged from $400 \mathrm{cal} \cdot \mathrm{cm}^{-1} \cdot \mathrm{d}^{-1}$ at $27 \mathrm{~m}$ elevation down to $380 \mathrm{cal} \cdot \mathrm{cm}^{-1} \cdot \mathrm{d}^{-1}$ at $87 \mathrm{~m}$ elevation (How, 1978). The test site, intermediate in elevation to the two stations, should historically receive about $390 \mathrm{cal} \cdot \mathrm{cm}^{-1} \cdot \mathrm{d}^{-1}$ solar radiation. Planting holes excavated in the lava were supplemented with about $15 \mathrm{~L}$ of Papai soil that had not been previously planted in papaya.

Helemano. The Helemano block was installed on 23 Oct. 1998 on the north shore of the island of Oahu. The Helemano site soil was a highly weathered Oxisol of low fertility, Lahaina silty clay (USDA, 1972). Elevation was $180 \mathrm{~m}$. The average daily temperature was $27^{\circ} \mathrm{C}$ in summer and $22^{\circ} \mathrm{C}$ in winter (USDA, 1972). The 30-year average (1932-75) solar radiation at the nearest weather station $(3.2 \mathrm{~km})$ was 468 $\mathrm{cal} \cdot \mathrm{cm}^{-1} \cdot \mathrm{d}^{-1}$ at $210 \mathrm{~m}$ elevation (How, 1978). Helemano received about $130 \mathrm{~cm}$ of rain per year and, except for periods of heavy rainfall, was drip-irrigated at 92 to $137 \mathrm{~m}^{3} \cdot \mathrm{ha}^{-1} \cdot \mathrm{week}^{-1}$ throughout the year.

Mokuleia. The Mokuleiablock was installed on 10 Mar. 1999 on the north shore of the island of Oahu. The Mokuleia site (elevation $=9 \mathrm{~m}$ ) had a fertile Mollisol soil, Waialua silty clay (USDA, 1972). The average daily temperature was $29^{\circ} \mathrm{C}$ in summer and $26^{\circ} \mathrm{C}$ in winter. The 30 -year average solar radiation at the nearest weather station $(6.4 \mathrm{~km})$ was $435 \mathrm{cal} \cdot \mathrm{cm}^{-1} \cdot \mathrm{d}^{-1}$ at $6 \mathrm{~m}$ elevation (How, 1978). The site received about $130 \mathrm{~cm}$ of rain peryear(USDA, 1972) and, except for periods of heavy rainfall, was drip-irrigated at the same rate as the Helemano site: 92 to $137 \mathrm{~m}^{3} \cdot \mathrm{ha}^{-1} \cdot$ week $^{-1}$ throughout the year.

\section{Field test design}

The experimental design was a randomized complete block with four or six replication plots containing three to five treatments as subplots consisting of a single row for each treatment. The treatments were designated as: CT, rooted cuttings; $\mathrm{MP}_{\mathrm{lo}}$, micropropagated plants 21 to $30 \mathrm{~cm}$ tall; $\mathrm{MP}_{\mathrm{sm}}^{\mathrm{lg}}$, micropropagated plants 12 to $20 \mathrm{~cm}$ tall; SD1, single seedlings; and SD5, 5 seedlings per hole. Subplots of treatments were randomized within each replication plot. The Keaau block was divided into four replication subplots containing five treatments $\left(\mathrm{CT}, \mathrm{MP}_{\mathrm{lg}}\right.$, $\left.\mathrm{MP}_{\mathrm{sm}}, \mathrm{SD} 1, \mathrm{SD} 5\right)$ planted as single rows of 20 plants each randomized among subplots for a total test size of 400 plants. The Helemano block was divided into six replication subplots containing three treatments (CT, MP, SD5) planted as single rows of 10 plants each randomized among subplots for a total test size of 180 plants. The Mokuleia block was divided into four replication subplots containing four treatments (CT, MP, SD1, SD5) planted as single rows of 28 plants each randomized among subplots for a total test size of 448 plants. Tree spacing was $1.50 \mathrm{~m}$ between trees within a row and $3 \mathrm{~m}$ between rows. For the single seedling treatment (SD1), a single SD was planted per 

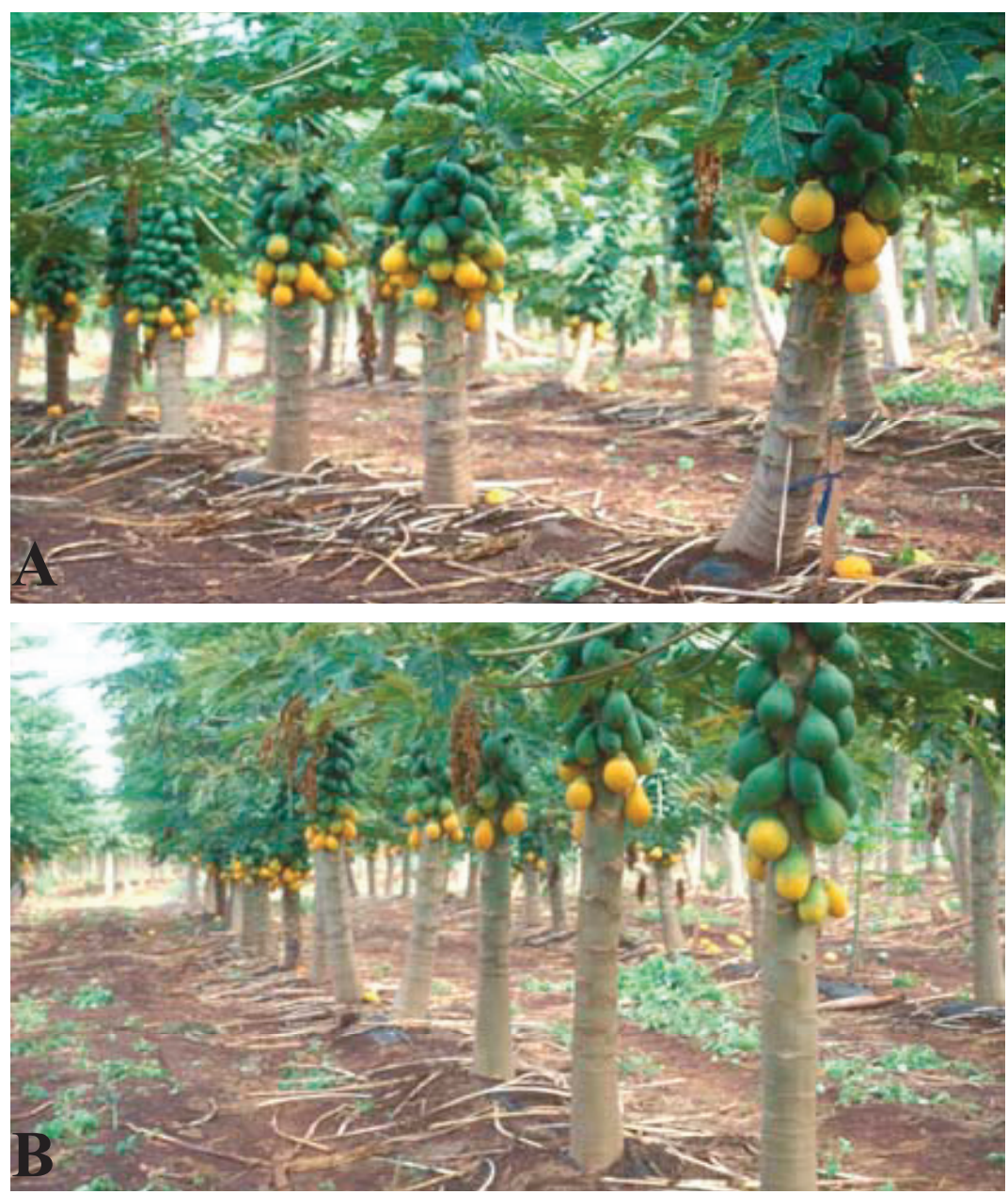

hole. For the multiple plant treatment, the SDs were planted five per hole (SD5), about $8 \mathrm{~cm}$ apart and thinned to a single hermaphrodite when flower buds appeared. To eliminate edge effects, each field block was surrounded by at least two border rows of SD5 plants of the same age as the test plants.

At all three sites, growers applied fertilizer and pest control chemicals according to their standard practice that consisted of broadcasting a formulation of $11 \mathrm{~N}-32 \mathrm{~K}_{2} \mathrm{O}$ fertilizer around each tree or they applied the formulation through the irrigation system at $20 \mathrm{~kg} \cdot \mathrm{ha}^{-1}$ every fourth week during the first 3 months of growth and then increased the amount to $80 \mathrm{~kg} \cdot \mathrm{ha}{ }^{-1}$ every fourth week. Supplemental $\mathrm{K}_{2} \mathrm{O}$ fertilization was added if deficiency symptoms appeared.

\section{Micropropagation}

A total of 350 micropropagated hermaphrodite plants were produced as described by Fitch et al. (2005). Briefly, 'Rainbow' papaya seeds were decontaminated with diluted commercial bleach, germinated on water agar, proliferated on modified Murashige and Skoog (1962) medium (MS0, Fitch et al., 2005) supplemented with $0.89 \mu \mathrm{M}$ benzylaminopurine (BA) and 1.1 $\mu \mathrm{M}$ naphthalene acetic acid (NAA), induced to root on MS/IBA medium without BA and NAA (MS0) but containing $9.84 \mu \mathrm{M}$ indolebutyric acid (IBA), then rooted in vermiculite medium moistened with half-strength MS0 medium containing $30 \mathrm{~g} \cdot \mathrm{L}^{-1}$ sucrose.
Ex vitro cuttings from stock plants of greenhouse-grown, micropropagated 'Rainbow' hermaphrodites were dipped in $0.1 \mathrm{~g}$ IBA per $100 \mathrm{~g}$ talc and rooted under intermittent mist irrigation on heating mats at $30{ }^{\circ} \mathrm{C}$ (Fitch et al., 2005). All of the rooted cuttings in the Keaau test were derived from the same lines of hermaphrodite 'Rainbow' seedlings used in the micropropagated plant treatment. Rooted cuttings in the Mokuleia and Helemano tests were a mixture of cuttings from the greenhouse stock plants and from lateral branches of mature, field-grown hermaphrodite 'Rainbow' trees. About $10 \%$ of the rooted cuttings were produced from mature trees. A total of 350 rooted cuttings were prepared for the field tests.

\section{Seedlings}

About 5500 'Rainbow' seedlings were germinated for the three field tests including border rows. In total, 600 seedlings were PCRtested (Deputy et al., 2002) for sex expression to obtain 252 hermaphrodite seedlings for two of the three locations, Keaau and Mokuleia. About 1700 seedlings were planted, five per hole, $5 \mathrm{~cm}$ apart, and thinned to 350 hermaphrodites.

Since rooted cuttings were larger and thicker in diameter than seedlings, two sizes of micropropagated plants were included in the Keaau test, large micropropagated plants $\left(\mathrm{MP}_{\mathrm{lg}}\right)$ that were equivalent in height but not diameter to the rooted cuttings $(21$ to $30 \mathrm{~cm}$ tall) and small micropropagated plants $\left(\mathrm{MP}_{\mathrm{sm}}\right)$

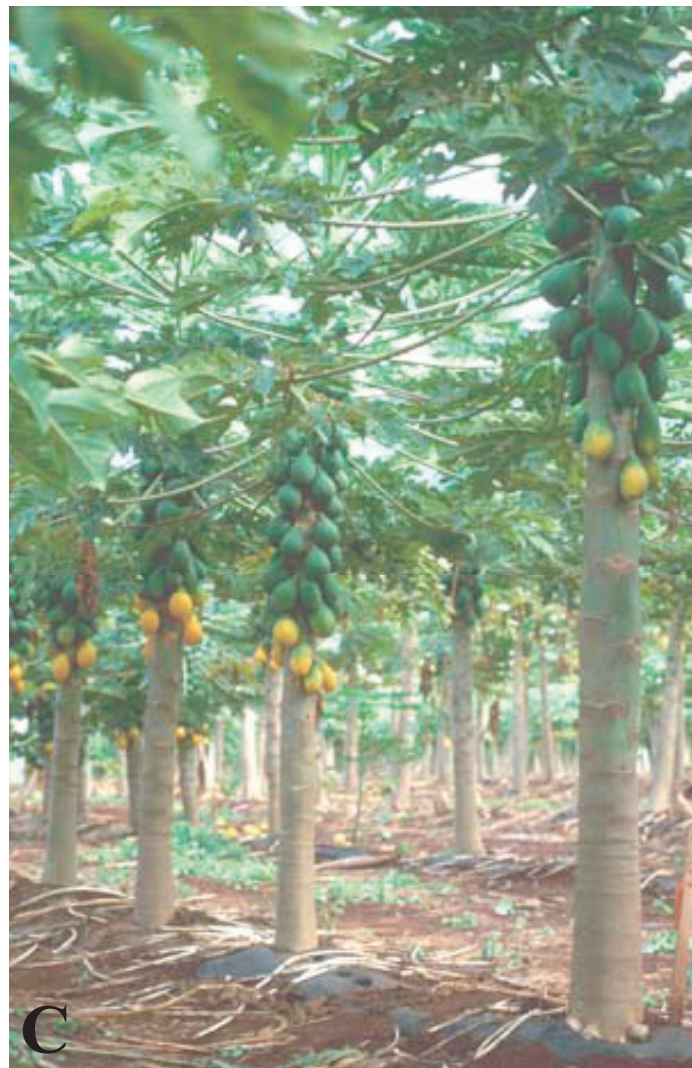

Fig. 1. Clonally propagated and seedling 'Rainbow' trees in the Mokuleia test. Three plant types are shown, (A) rooted cuttings (CTs), (B) micropropagated plants (MPs), and (C) thinned seedlings (SD5s). All of the photographs were taken on the same harvest date. Bearing height of the plant types differed significantly.

that were comparable to the seedlings (12 to $20 \mathrm{~cm}$ tall).

\section{Data collection and analysis}

The number and weight, to the nearest $0.5 \mathrm{~kg}$, of fruit at color break to $1 / 4$ ripe were recorded for every tree in each subplot for 1 week each month. Data are presented as the 1 -week mean per tree of subplots (plant type) within the site block per month. Significance of the data was calculated from analysis of variance in treatment subplots and expressed as the least significant difference (LSD) among treatments each month at $P<0.05$ (Statistix 7 for Windows). Data were analyzed for the effect of location and time by combining the datasets for Keaau, Helemano, and Mokuleia. The yields reported are only a fraction of the true yields because in commercial practice, growers harvest their fields four or more times each month. We estimated annual yields at Mokuleia and Helemano by multiplying the 1 -week cumulative yields in the eighth month (last month of harvest) by four to get a monthly estimate and then by 12 for an estimated annual yield. Unlike Keaau, the two sites on Oahu were not harvested for a full 12 months because the trees grew too tall to reach the fruit. The cumulative yield per tree in 12 months at Keaau was multiplied by four to estimate the annual yield. Annual yields per ha were estimated by multiplying mean tree yields by 1650 which is the average density of trees per ha in commercial orchards. 


\section{Results}

Harvests commenced 8 to 10 months after planting. Early differences in yield between plant types were most important economically; however, differences in fruit bearing height were the most striking (Fig. 1). Yield data over 6 months of harvest at Keaau, Helemano, and Mokuleia were analyzed together to evaluate the effects of time (month of harvest), location, and plant type (Table 1). Replication differences were not significant for any yield characteristic. The fruit weight differences were highly significant $(P<0.001)$ for all sources of variation except replication. Differences in number of fruit per tree were significant $(P<0.05)$ for plant type and highly significant $(P<0.001)$ for month of harvest and location. Differences in individual fruit weight were highly significant $(P<0.001)$ for plant type and time but not location. Since replication had no effect, the differences in each of the yield characteristics were highly significant for pooled data so that each characteristic was separately analyzed for the 1-week harvest of each month.

The weight and number of fruit per tree per week for each month in Keaau varied significantly with time among plant types (Table 2). However, the individual weight per fruit did not differ between plant types.

Both types of clonally propagated plants, CTs and MPs, had significantly higher number and weight of fruit in the first 3 months of harvest compared to SD5 plants $(P<0.05)$. Yields of the $\mathrm{MP}_{\mathrm{sm}}$ and SD1 plants were not significantly different. Weight of fruit per tree at the first harvest, 9 months after transplanting, was closely correlated to the percentage of trees in bud in the third month after transplanting (Fitch et al., 2005). The $r^{2}$ correlation coefficient was 0.9758 $(P<0.002)$, suggesting that a high percentage of budding in the third month of growth is a good predictor of high yields. Although hermaphrodite seedlings (SD1) were single-planted like
CTs and MPs, their harvest yields were less than those of the clonally propagated plants at the third harvest (Table 2, Fig. 2). After the third harvest, the fruit weight and number of all plant types were generally not significantly different. The early high yields of clonally propagated plants produced 8 months of significantly higher cumulative yields compared to SD5 $(P<0.05)$, Fig. 3A). Subsequent cumulative yields were not significantly different but yields of clonally propagated plants continued to be the highest for the rest of the crop cycle (Fig. 3A).

The early yield of SD5 plants in Helemano was significantly higher than that of CTs in the third harvest only, thereafter the yields were not significantly different (Table 3 ). MP yields were higher than SD5 plants for the fourth and fifth harvests. In general, the differences among plant types diminished with crop development over time. Individual fruit weight varied in each month but in no obvious pattern. Correlation between percentage of trees in bud in the third month of growth (Fitch et al., 2005) and yield per tree in the third harvest was high with $r^{2}=$ 0.9673 at $P<0.12$. The high early yields of MPs and CTs in Helemano resulted in cumulative yields that were significantly higher than those of SD5 plants throughout the cropping cycle (Fig. 3B). The early yield advantage of the clonally propagated plants was never surpassed by SD5s for the duration of the experiment when all treatments were essentially the same.

The large differences in yield of fruit between plant types in Keaau (Table 2, Fig. 2A) were not evident in Mokuleia (Table 4, Fig. 2C). The largest differences measured in Keaau were in the second month of harvest only. In this harvest, significantly higher yields were recorded for CTs and SD1s compared to SD5s, and the number of fruit per tree was significantly higher for CT and SD1 plants compared to SD5 plants. The yield of MPs was not significantly higher than thinned seedlings. Although there were no significant differences in earliness of flowering in the second month of growth in Mokuleia (Fitch et al., 2005) nor in yield during the second month of harvest (Table 4), there was good correlation between the percentage of plants in bud and yield, $r^{2}=$ $0.89, P<0.05$. Cumulative yields of CT and SD1 plants were significantly higher than SD5 plants for two out of eight harvests in Mokuleia (Fig. 3C). After the third harvest, the cumulative yields maintained a constant difference. Cumulative annual yields extrapolated from the eighth and final harvest to estimate annual yields for Helemano showed that MPs were the most productive at $259,875 \mathrm{~kg} \cdot \mathrm{ha}^{-1}$, followed by CTs, 220,077 $\mathrm{kg} \cdot \mathrm{ha}^{-1}$, and SD5s, 203,247 $\mathrm{kg} \cdot \mathrm{ha}^{-1}$ (Table 5). All yields are considered to be extremely high for papaya. The calculated annual cumulative yields for Keaau, 84,200 to $118,223 \mathrm{~kg} \cdot \mathrm{ha}^{-1}$, were close to the yield reported for a field test of 'Rainbow' in Puna in lava soil, 121,000 kg.ha- (Ferreira et al., 2002). The solar radiation in Puna is $450 \mathrm{cal} \cdot \mathrm{cm}^{-2} \cdot \mathrm{d}^{-1}$,

Table 1. Analysis of variance (ANOVA) for various yield characteristics of papaya as influenced by plant type (TYPE), month of harvest (MON), and location (LOC).

\begin{tabular}{lrccc}
\hline $\begin{array}{l}\text { Source of } \\
\text { variation }\end{array}$ & df & $\begin{array}{c}\text { Wt of fruit/ } \\
\text { tree }(\mathrm{kg})\end{array}$ & $\begin{array}{c}\text { No. of } \\
\text { fruit/tree }\end{array}$ & $\begin{array}{c}\text { Mean wt/ } \\
\text { fruit }\end{array}$ \\
\hline Plant type (TYPE) & 2 & $* * *$ & $*$ & $* * *$ \\
Replication (REP) & 5 & NS & NS & NS \\
Month of harvest (MON) & 5 & $* * *$ & $* * *$ & $* * *$ \\
Location $(\mathrm{LOC})$ & 2 & $* * *$ & & NS \\
TYPE $\times$ REP $\times$ MON $\times$ LOC & 237 & & & \\
\hline
\end{tabular}

NS, ${ }^{*, * *, * * *}$ Nonsignificant or significant at $P<0.05,0.01$, or 0.001 , respectively.

Table 2. Monthly 1-week yield per tree data for cloned and seedling papaya plants at Keaau.

\begin{tabular}{|c|c|c|c|c|c|c|c|c|c|c|c|c|c|c|c|}
\hline \multirow{6}{*}{$\begin{array}{l}\text { Plant } \\
\text { type }\end{array}$} & \multicolumn{15}{|c|}{ Month } \\
\hline & Jan. 1999 & Feb. 1999 & Mar. 1999 & Apr. 1999 & May 1999 & June 1999 & July 1999 & Aug. 1999 & Sept. 1999 & Oct. 1999 & Nov. 1999 & Dec. 1999 & Jan. 2000 & Mar. 2000 & June 2000 \\
\hline & \multicolumn{15}{|c|}{ Months after transplanting } \\
\hline & $9^{2}$ & 10 & 11 & 12 & 13 & 14 & 15 & 16 & 17 & 18 & 19 & 20 & 21 & 23 & $26^{y}$ \\
\hline & \multicolumn{15}{|c|}{ Harvest } \\
\hline & 1 & 2 & 3 & 4 & 5 & 6 & 7 & 8 & 9 & 10 & 11 & 12 & 13 & 15 & 18 \\
\hline \multicolumn{16}{|c|}{ Weight of fruit (kg) } \\
\hline $\mathrm{CT}$ & $1.58 \mathrm{a}^{\mathrm{w}}$ & $2.11 \mathrm{a}$ & $2.49 \mathrm{a}$ & $1.91 \mathrm{a}$ & $1.08 \mathrm{a}$ & $1.00 \mathrm{a}$ & $0.82 \mathrm{ab}$ & $0.81 \mathrm{ab}$ & $0.90 \mathrm{a}$ & $0.83 \mathrm{a}$ & $0.93 \mathrm{a}$ & $1.63 \mathrm{a}$ & $1.56 \mathrm{a}$ & $1.65 \mathrm{a}$ & $0.80 \mathrm{a}$ \\
\hline $\mathrm{MP}_{\mathrm{g}}$ & $1.41 \mathrm{a}$ & $1.33 \mathrm{a}$ & $2.02 \mathrm{a}$ & $1.64 \mathrm{a}$ & $1.41 \mathrm{a}$ & $0.80 \mathrm{a}$ & $0.66 \mathrm{ab}$ & $0.58 \mathrm{~b}$ & $1.33 \mathrm{a}$ & $0.93 \mathrm{a}$ & $1.12 \mathrm{a}$ & $1.75 \mathrm{a}$ & $1.70 \mathrm{a}$ & $1.60 \mathrm{a}$ & $0.71 \mathrm{a}$ \\
\hline $\mathrm{MP}_{\mathrm{sm}}^{\mathrm{lg}}$ & $0.76 \mathrm{~b}$ & $1.96 \mathrm{a}$ & $2.27 \mathrm{a}$ & $2.01 \mathrm{a}$ & $1.44 \mathrm{a}$ & $1.22 \mathrm{a}$ & $0.93 \mathrm{a}$ & $1.00 \mathrm{a}$ & $1.27 \mathrm{a}$ & $0.64 \mathrm{a}$ & $1.02 \mathrm{a}$ & $1.62 \mathrm{a}$ & $1.79 \mathrm{a}$ & $1.52 \mathrm{a}$ & $0.69 \mathrm{a}$ \\
\hline SD1 & $0.42 \mathrm{bc}$ & $1.46 \mathrm{a}$ & $1.12 \mathrm{~b}$ & $1.17 \mathrm{a}$ & $1.20 \mathrm{a}$ & $0.82 \mathrm{a}$ & $0.50 \mathrm{~b}$ & $0.77 \mathrm{ab}$ & $1.08 \mathrm{a}$ & $0.69 \mathrm{a}$ & $0.87 \mathrm{a}$ & $1.28 \mathrm{a}$ & $1.40 \mathrm{a}$ & $1.62 \mathrm{a}$ & $0.71 \mathrm{a}$ \\
\hline SD5 & $0.02 \mathrm{c}$ & $0.22 b$ & $0.94 \mathrm{~b}$ & $1.45 \mathrm{a}$ & $1.36 \mathrm{a}$ & $1.37 \mathrm{a}$ & $0.68 \mathrm{ab}$ & $1.15 \mathrm{a}$ & $1.33 \mathrm{a}$ & $0.70 \mathrm{a}$ & $0.92 \mathrm{a}$ & $1.59 \mathrm{a}$ & $1.68 \mathrm{a}$ & $1.77 \mathrm{a}$ & $0.91 \mathrm{a}$ \\
\hline \multicolumn{16}{|c|}{ Number of fruit per tree } \\
\hline $\mathrm{CT}$ & $2.40 \mathrm{a}$ & $3.35 \mathrm{a}$ & $4.19 \mathrm{a}$ & $3.04 \mathrm{a}$ & $1.80 \mathrm{a}$ & $\mathrm{ND}^{\mathrm{v}}$ & $1.75 \mathrm{a}$ & $1.39 \mathrm{ab}$ & ND & ND & $1.37 \mathrm{a}$ & $2.46 \mathrm{a}$ & $2.48 \mathrm{a}$ & ND & $1.61 \mathrm{a}$ \\
\hline $\mathrm{MP}_{\mathrm{gg}}$ & $2.42 \mathrm{a}$ & $2.91 \mathrm{ab}$ & $4.62 \mathrm{a}$ & $2.99 \mathrm{a}$ & $2.31 \mathrm{a}$ & ND & $1.12 \mathrm{~b}$ & $0.91 \mathrm{~b}$ & ND & ND & $1.61 \mathrm{a}$ & $2.65 \mathrm{a}$ & $2.70 \mathrm{a}$ & ND & $1.50 \mathrm{a}$ \\
\hline $\mathrm{MP}_{\mathrm{sm}}^{\mathrm{gg}}$ & $1.16 \mathrm{~b}$ & $3.00 \mathrm{ab}$ & $4.63 \mathrm{a}$ & $3.33 \mathrm{a}$ & $2.40 \mathrm{a}$ & ND & $1.73 \mathrm{a}$ & $1.27 \mathrm{~b}$ & ND & ND & $1.48 \mathrm{a}$ & $2.42 \mathrm{a}$ & $2.81 \mathrm{a}$ & ND & $1.35 \mathrm{a}$ \\
\hline SD1 & $0.73 \mathrm{bc}$ & $1.99 \mathrm{~b}$ & $2.64 \mathrm{ab}$ & $2.28 \mathrm{a}$ & $2.21 \mathrm{a}$ & ND & $1.20 \mathrm{ab}$ & $1.48 \mathrm{ab}$ & ND & ND & $1.14 \mathrm{a}$ & $2.01 \mathrm{a}$ & $2.22 \mathrm{a}$ & ND & $1.62 \mathrm{a}$ \\
\hline SD5 & $0.04 \mathrm{c}$ & $0.40 \mathrm{c}$ & $2.16 \mathrm{~b}$ & $2.45 \mathrm{a}$ & $2.37 \mathrm{a}$ & ND & $1.25 \mathrm{ab}$ & $2.07 \mathrm{a}$ & ND & ND & $1.61 \mathrm{a}$ & $2.59 \mathrm{a}$ & $2.71 \mathrm{a}$ & ND & $1.78 \mathrm{a}$ \\
\hline \multicolumn{16}{|c|}{ Mean weight per fruit $(\mathrm{g})$} \\
\hline $\mathrm{CT}$ & $644 \mathrm{a}$ & $619 a$ & $491 \mathrm{a}$ & $627 \mathrm{a}$ & $612 \mathrm{a}$ & ND & $519 \mathrm{a}$ & $597 \mathrm{a}$ & ND & ND & $694 \mathrm{a}$ & $669 a$ & $632 \mathrm{a}$ & ND & $519 a$ \\
\hline $\mathrm{MP}_{\mathrm{lg}}$ & $603 \mathrm{a}$ & $476 \mathrm{a}$ & $469 \mathrm{a}$ & $550 \mathrm{a}$ & $609 \mathrm{a}$ & ND & $602 \mathrm{a}$ & $646 \mathrm{a}$ & ND & ND & $693 \mathrm{a}$ & $684 \mathrm{a}$ & $628 \mathrm{a}$ & ND & $489 \mathrm{a}$ \\
\hline $\mathrm{MP}_{\mathrm{sm}}^{\mathrm{lg}}$ & $649 a$ & $653 \mathrm{a}$ & $490 \mathrm{a}$ & $605 a$ & $599 \mathrm{a}$ & ND & $540 \mathrm{a}$ & $791 \mathrm{a}$ & ND & ND & $666 \mathrm{a}$ & $698 \mathrm{a}$ & $635 \mathrm{a}$ & ND & $511 \mathrm{a}$ \\
\hline SD1 & $516 \mathrm{a}$ & $697 \mathrm{a}$ & $478 \mathrm{a}$ & $513 \mathrm{a}$ & $524 \mathrm{a}$ & ND & $443 \mathrm{a}$ & $538 \mathrm{a}$ & ND & ND & $784 \mathrm{a}$ & $700 \mathrm{a}$ & $681 \mathrm{a}$ & ND & $508 \mathrm{a}$ \\
\hline SD5 & $555 \mathrm{a}$ & $422 \mathrm{a}$ & $460 \mathrm{a}$ & $595 \mathrm{a}$ & $574 \mathrm{a}$ & ND & $547 \mathrm{a}$ & $569 \mathrm{a}$ & ND & ND & $580 \mathrm{a}$ & $676 \mathrm{a}$ & $651 \mathrm{a}$ & ND & $547 \mathrm{a}$ \\
\hline
\end{tabular}

${ }^{2}$ First harvest.

yLast harvest.

${ }^{\mathrm{x}} \mathrm{CT}=$ cuttings, $\mathrm{MP}=$ large micropropagated plants, $\mathrm{MP}=$ small micropropagated plants, $\mathrm{SD} 1=$ single hermaphrodite seedlings, $\mathrm{SD} 5=$ thinned seedlings

"Mean values within a column followed by different letters indicate significant differences among treatments $(P<0.05)$ according to ANOVA (LSD).

$\mathrm{ND}=$ no data taken 

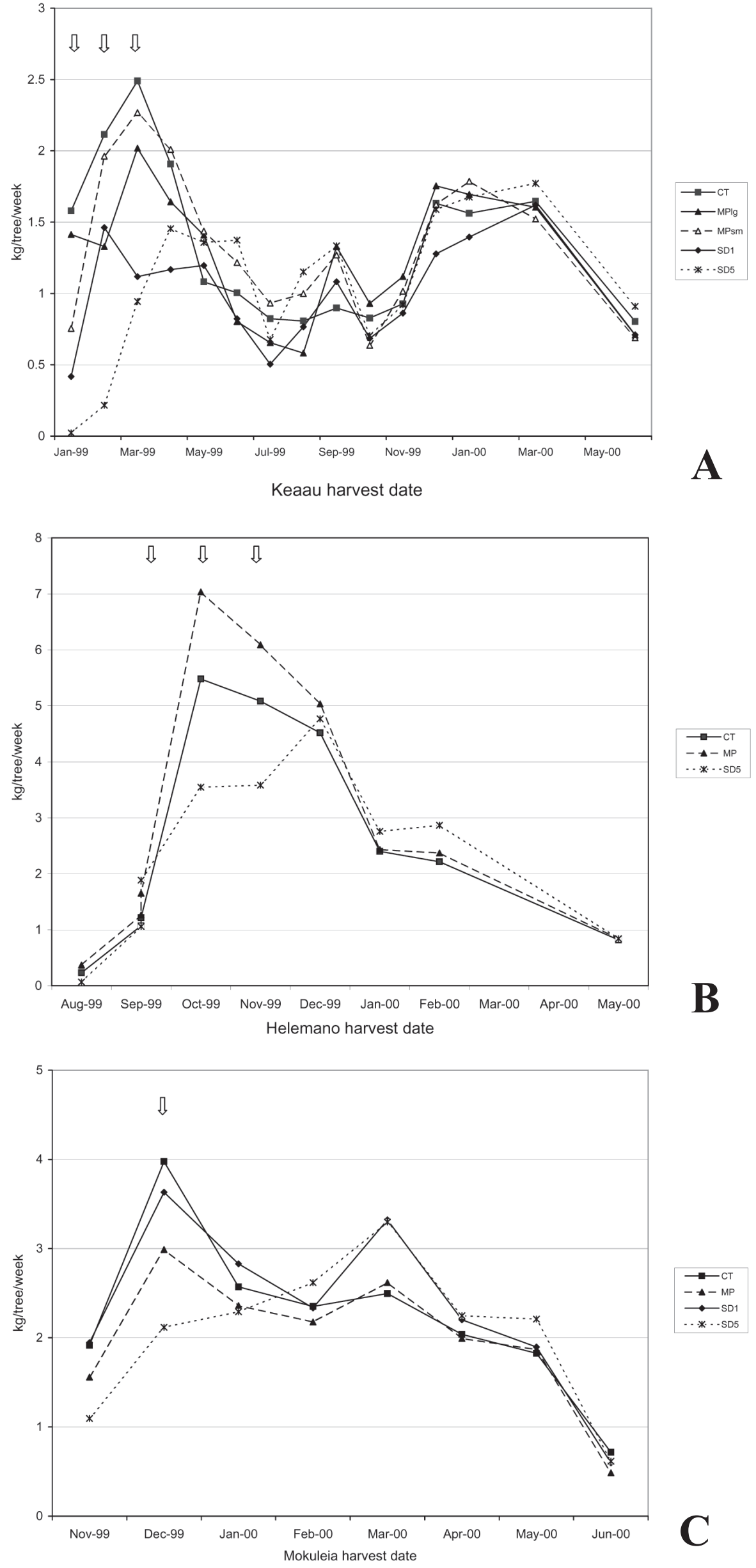

15 units higher than that in Mokuleia (435 $\left.\mathrm{cal} \cdot \mathrm{cm}^{-2} \cdot \mathrm{d}^{-1}\right)$ and about $61 \mathrm{cal} \cdot \mathrm{cm}^{-2} \cdot \mathrm{d}^{-1}$ higher than in Keaau.

\section{Discussion}

Clonally propagated papayas were reported to bear fruit earlier and lower on the trunk (Allan, 1964, 1993; Chan and Teo, 2002; Drew, 1988; Drew and Vogler, 1993; Fitch et al., 2005), and to have higher yields compared to singleplanted seedlings (Drew and Vogler, 1993). The experiment presented here corroborates the Drew and Vogler (1993) study and is the only one comparing clonally propagated trees, single-planted seedlings, and multiple-planted then thinned seedlings, the latter being the typical cropping system used in many papaya growing operations worldwide. Additionally, since the experiment was carried out in three divergent locations, the environmental effects on yield of papaya, regardless of cropping system, are important considerations for growers.

Annual cumulative yields extrapolated from one harvest per week for each month for all cropping systems, CTs, MPs, SD1s, and SD5s, were higher in Mokuleia than in Keaau by $66 \%$, $69 \%$ to $74 \%\left(\mathrm{MP}_{\mathrm{lg}}\right.$ and $\left.\mathrm{MP}_{\mathrm{sm}}\right), 46 \%$, and $54 \%$ (Table 5), respectively. Helemano had the highest yields for all three plant types, CTs, MPs, and SD5s (Table 5), higher than in Mokuleia by $20 \%, 39 \%$, and $20 \%$, respectively. The locations differ in average daily solar radiation, average winter and summer temperature and rainfall, and in soil type. Planting time was comparable in Keaau and Mokuleia. Fields were established about 1 year apart in mid-spring and early spring, respectively, enabling the young transplants to grow through the juvenile phase in the beginning of the warm spring and summer growing season. On the other hand, trees in the late autumn Helemano planting spent the juvenile phase in winter. Helemano had the highest solar radiation and elevation but lowest average temperatures and moderately fertile soil. The early yields at Helemano were low 11 months after planting and comparable to those in Keaau (Tables 4 and 2 ) and in contrast to Mokuleia (Table 3). But later in the harvest cycle, Helemano yields in the $12^{\text {th }}$ to $14^{\text {th }}$ months after planting were very high. The peak yield for the clonally propagated plants occurred in the $12^{\text {th }}$ month after planting while the thinned seedlings peaked in the $14^{\text {th }}$ month. This extraordinarily high yield could be due to a combination of planting time and high solar radiation. Drew and Vogler (1993)

Fig. 2. Yield per tree of cloned and seedlings papaya plants for 1 week per month (kg per tree) at Keaau (A), Helemano (B), and Mokuleia (C). Keaau yields of clonally propagated plants were significantly higher $(P<0.05$, arrows) for 3 months compared to thinned seedlings. Helemano yields in three harvests differed significantly. Mokuleia second harvest yields of cuttings and single seedlings but not micropropagated plants were higher than thinned seedlings. The graphs show the monthly fluctuations due to season, weather conditions, etc. $\mathrm{CT}=$ cuttings, $\mathrm{MP}=$ large micropropagated plants, $\mathrm{MP}_{\mathrm{sm}}=$ small micropropagated plants, $\mathrm{SD} 1=$ single hermaphrodite seedlings, SD5 = thinned seedlings 

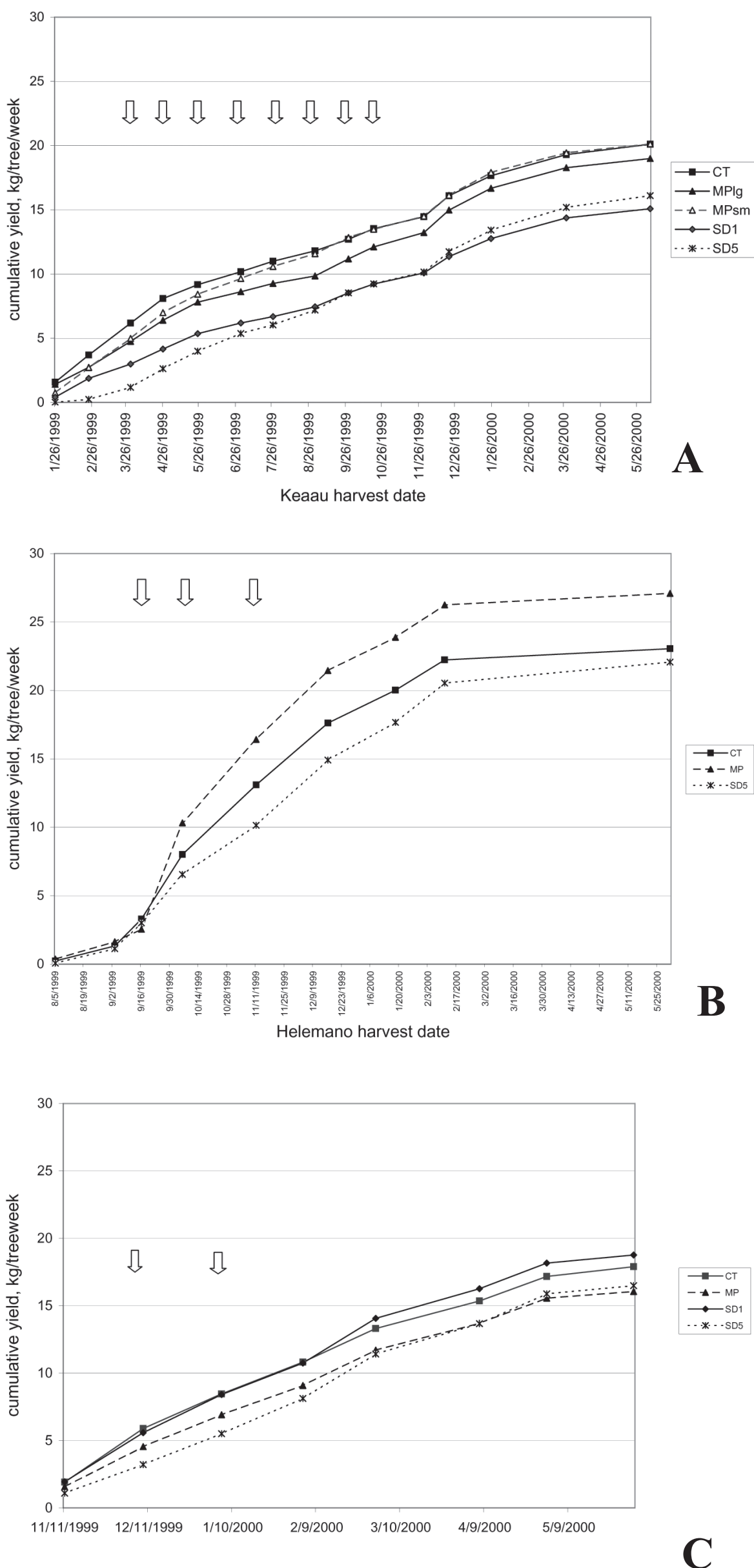

Mokuleia harvest date reported that in Australia, the normal planting time is just prior to winter. Over-wintering may allow plants to build up reserves of nutrients to produce many fruit early in the cropping cycle. The fact that both clonally propagated trees and thinned seedlings in Helemano showed high yields suggests that for that location and perhaps others, planting a crop in late autumn is a good cropping practice.

Cumulative yields of most of the clonally propagated plant types in all three locations were never surpassed by those of seedlings. The exceptions were micropropagated plants in Mokuleia that yielded less than thinned seedlings and single-planted seedlings that out-yielded all other plant types. Mokuleia with its high temperatures and soil fertility and low elevation may foster such rapid growth and development of seedlings that the use of clonally propagated plants may not be justified for yield. However, the shorter harvest height of clonally propagated plants (Fitch et al., 2005 ) could provide sufficient savings for the grower to invest in cloned plants. Helemano and Keaau showed the highest yields by clonally propagated plants compared to thinned seedlings, justifying use of cloned plants. Keaau with its low solar radiation, soil fertility, and yields, may benefit most from use of clonally propagated plants. Although SD1 plants did not have to compete for light and nutrients during early growth, some juvenile factor(s) apparently affected yield in Keaau as had been observed for growth (Fitch et al., 2005). This juvenility factor was most pronounced in Keaau seedling yield. The slightly lower yield of SD1 compared to SD5 suggests that in Keaau, multiple-planting was not detrimental to seedling yield as was juvenility.

Yield data from the lava fields planted in the springtime corroborate those of Drew and Vogler (1993) who reported that micropropagated papayas planted in the springtime had higher yields than single-planted seedlings. Yields of the fall-planted Helemano site, however, are contrary to those of Drew and Vogler (1993) who reported that micropropagated plants established in the cooler winter season did not show a yield advantage over single-planted seedlings. Micropropagated plants were the highest yielding group in Helemano. Drew and Vogler (1993) reported that planting date affected node number and maturation. The milder winters in Hawaii may not affect plant development as much as in Australia where dioecious, cold tolerant cultivars are grown. Drew and Vogler (1993) observed that plants micropropagated from adult tissues but not juveniles (inconsistent results) had higher yields than single-planted seedlings when planted in spring. We did not differentiate between micropropagated plants from seedlings or mature plants; however,

Fig. 3. Cumulative monthly 1-week data for cloned and seedling papaya plants at Keaau (A), Helemano (B), and Mokuleia (C). At Keaau, the cumulative yield of clonally propagated plants over other treatments was significantly greater $(P<0.05$, see arrow $)$ over eight harvests, at Helemano over six harvests, and at Moluleia over two harvests. 
Table 3. Monthly 1-week yield per tree data for cloned and seedling papaya plants at Helemano.

\begin{tabular}{|c|c|c|c|c|c|c|c|c|c|}
\hline & \multicolumn{9}{|c|}{ Month } \\
\hline & Aug. 1999z & Sept. 1999 a & Sept. 1999 b & Oct. 1999 & Nov. 1999 & Dec. 1999 & Jan. 2000 & Feb. 2000 & May 2000 \\
\hline & 10 & $11 \mathrm{a}$ & $11 \mathrm{~b}$ & 12 & 13 & 14 & 15 & 16 & 19 \\
\hline type ${ }^{x}$ & 1 & 2 & 3 & 4 & 5 & 6 & 7 & 8 & 9 \\
\hline \multicolumn{10}{|c|}{ Weight of fruit $(\mathrm{kg})$} \\
\hline $\mathrm{CT}$ & $0.23 \mathrm{a}^{\mathrm{w}}$ & $1.07 \mathrm{a}$ & $1.22 \mathrm{~b}$ & $5.46 \mathrm{ab}$ & $5.09 \mathrm{ab}$ & $4.52 \mathrm{a}$ & $2.40 \mathrm{a}$ & $2.22 \mathrm{a}$ & $0.82 \mathrm{a}$ \\
\hline \multicolumn{10}{|c|}{ Number of fruit per tree } \\
\hline $\mathrm{CT}$ & $0.65 \mathrm{a}$ & $2.27 \mathrm{a}$ & $2.32 \mathrm{~b}$ & $9.70 \mathrm{a}$ & $8.11 \mathrm{a}$ & $9.17 \mathrm{a}$ & $5.00 \mathrm{a}$ & $4.41 \mathrm{a}$ & $1.73 \mathrm{a}$ \\
\hline MP & $0.77 \mathrm{a}$ & $2.29 \mathrm{a}$ & $3.04 \mathrm{ab}$ & $12.50 \mathrm{a}$ & $8.68 \mathrm{a}$ & $9.30 \mathrm{a}$ & $4.90 \mathrm{a}$ & $4.58 \mathrm{a}$ & $1.78 \mathrm{a}$ \\
\hline SD5 & $0.15 \mathrm{a}$ & $1.90 \mathrm{a}$ & $3.60 \mathrm{a}$ & $5.87 \mathrm{~b}$ & $5.40 \mathrm{~b}$ & $9.35 \mathrm{a}$ & $5.62 \mathrm{a}$ & $5.28 \mathrm{a}$ & $2.09 \mathrm{a}$ \\
\hline \multicolumn{10}{|c|}{ Mean weight per fruit ( $\mathrm{g}$ ) } \\
\hline CT & $503 \mathrm{a}$ & $440 \mathrm{~b}$ & $530 \mathrm{a}$ & $550 \mathrm{a}$ & $610 \mathrm{a}$ & $480 \mathrm{a}$ & $460 \mathrm{a}$ & $480 \mathrm{a}$ & $395 \mathrm{a}$ \\
\hline MP & $472 \mathrm{a}$ & $460 \mathrm{~b}$ & $500 \mathrm{a}$ & $490 \mathrm{~b}$ & $610 \mathrm{a}$ & $950 \mathrm{a}$ & $430 \mathrm{a}$ & $480 \mathrm{a}$ & $394 \mathrm{a}$ \\
\hline
\end{tabular}

${ }^{2}$ First harvest.

${ }^{y}$ Last harvest.

${ }^{\mathrm{x}} \mathrm{CT}=$ cuttings, $\mathrm{MP}=$ micropropagated plants, $\mathrm{SD} 5=$ thinned seedlings.

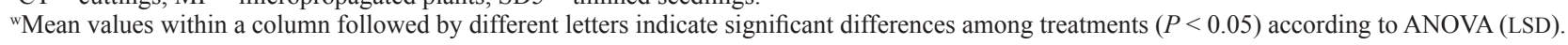

Table 4. Monthly 1-week yield per tree data for cloned and seedling papaya plants at Mokuleia.

\begin{tabular}{|c|c|c|c|c|c|c|c|c|}
\hline & \multicolumn{8}{|c|}{ Month } \\
\hline & Nov. 1999 & Dec. 1999 & Jan. 2000 & Feb. 2000 & Mar. 2000 & Apr. 2000 & May 2000 & June $2000^{z}$ \\
\hline & \multicolumn{8}{|c|}{ Months after transplanting } \\
\hline & 8 & 9 & 10 & 11 & 12 & 13 & 14 & 15 \\
\hline type $^{z}$ & 1 & 2 & 3 & 4 & 5 & 6 & 7 & 8 \\
\hline \multicolumn{9}{|c|}{ Weight of fruit (kg) } \\
\hline $\mathrm{CT}$ & $1.92 \mathrm{a}^{\mathrm{x}}$ & $3.97 \mathrm{a}$ & $2.57 \mathrm{a}$ & $2.35 \mathrm{a}$ & $2.50 \mathrm{a}$ & $2.04 \mathrm{a}$ & $1.83 \mathrm{a}$ & $0.72 \mathrm{a}$ \\
\hline SD5 & $1.10 \mathrm{a}$ & $2.12 \mathrm{~b}$ & $2.29 \mathrm{a}$ & $2.62 \mathrm{a}$ & $3.30 \mathrm{a}$ & $2.25 \mathrm{a}$ & $2.21 \mathrm{a}$ & $0.61 \mathrm{a}$ \\
\hline \multicolumn{9}{|c|}{ Number of fruit per tree } \\
\hline CT & $3.11 \mathrm{a}$ & $7.72 \mathrm{a}$ & $5.33 \mathrm{a}$ & $4.65 \mathrm{a}$ & $4.86 \mathrm{a}$ & $3.65 \mathrm{a}$ & $3.34 \mathrm{a}$ & $1.63 \mathrm{a}$ \\
\hline MP & $2.44 \mathrm{a}$ & $6.32 \mathrm{ab}$ & $4.75 \mathrm{a}$ & $4.50 \mathrm{a}$ & $4.51 \mathrm{a}$ & $3.53 \mathrm{a}$ & $3.31 \mathrm{a}$ & $0.92 \mathrm{a}$ \\
\hline SD1 & $3.03 \mathrm{a}$ & $6.93 \mathrm{a}$ & $5.45 \mathrm{a}$ & $4.51 \mathrm{a}$ & $6.12 \mathrm{a}$ & $3.98 \mathrm{a}$ & $3.76 \mathrm{a}$ & $1.43 \mathrm{a}$ \\
\hline SD5 & $1.99 \mathrm{a}$ & $4.37 \mathrm{~b}$ & $4.38 \mathrm{a}$ & $4.13 \mathrm{a}$ & $6.07 \mathrm{a}$ & $4.42 \mathrm{a}$ & $4.37 \mathrm{a}$ & $1.41 \mathrm{a}$ \\
\hline \multicolumn{9}{|c|}{ Mean weight per fruit (g) } \\
\hline
\end{tabular}

${ }^{2}$ Last harvest.

${ }^{\mathrm{y}} \mathrm{CT}=$ cuttings, $\mathrm{MP}=$ micropropagated plants, $\mathrm{SD} 1=$ single hermaphrodite seedlings, $\mathrm{SD} 5=$ thinned seedlings.

${ }^{\times}$Mean values within a column followed by different letters indicate significant differences among treatments $(P<0.05)$ according to ANOVA (LSD).

Table 5. Estimates of cumulative annual yields per tree and yields per hectare for cloned and seedling papaya plants at three locations; $\mathrm{S}=$ small plants, $\mathrm{L}=$ large plants.

\begin{tabular}{|c|c|c|c|c|c|c|}
\hline \multirow[b]{2}{*}{ Treatment ${ }^{\mathrm{z}}$} & \multicolumn{3}{|c|}{ Yield (kg/tree/year) } & \multicolumn{3}{|c|}{ Yield $\left(\mathrm{kg} \cdot \mathrm{ha}^{-1} \cdot \mathrm{year}^{-1}\right)$} \\
\hline & Keaau & Helemano & Mokuleia & Keaau & Helemano & Mokuleia \\
\hline$\overline{\mathrm{CT}}$ & $70.62 \mathrm{a}^{\mathrm{y}}$ & $133.38 \mathrm{a}$ & $107.34 \mathrm{a}$ & $116,523 \mathrm{a}$ & 220,077 a & $177,111 \mathrm{a}$ \\
\hline MP & $\begin{array}{l}71.65 \mathrm{a}(\mathrm{S}) \\
66.71 \mathrm{a}(\mathrm{L})\end{array}$ & $157.50 \mathrm{a}$ & $96.30 \mathrm{a}$ & $\begin{array}{l}118,223 \text { a (S) } \\
110,072 \text { a (L) }\end{array}$ & $259,875 \mathrm{a}$ & $158,895 \mathrm{a}$ \\
\hline SD1 & $51.03 \mathrm{a}$ & $\mathrm{ND}^{\mathrm{x}}$ & $111.95 \mathrm{a}$ & $84,200 \mathrm{a}$ & ND & $184,724 \mathrm{a}$ \\
\hline SD5 & $53.68 \mathrm{a}$ & $123.18 \mathrm{a}$ & $98.94 \mathrm{a}$ & $88,572 \mathrm{a}$ & 203,247 a & $163,251 \mathrm{a}$ \\
\hline
\end{tabular}

${ }^{2} \mathrm{CT}=$ cuttings, $\mathrm{MP}=$ micropropagated plants, $\mathrm{SD} 1=$ single seedlings, $\mathrm{SD} 5=$ thinned seedlings.

${ }^{y}$ Mean values within a column followed by different letters indicate significant differences among treatments $(P<0.05)$ according to ANOVA (LSD).

${ }^{\mathrm{x}} \mathrm{ND}=$ no data taken.

about $90 \%$ of the MPs were derived from in vitro-germinated seedlings.

Seeds are relatively inexpensive compared to in vitro-micropropagated plants and rooted cuttings. Seeds for 1 ha cost $\$ 580$ (Hawaii Papaya Industry Association, 2004) while 4 ha of micropropagated 'Rainbow' were sold to growers for $\$ 2250 /$ ha (M. Fitch, personal observation). Rooted cuttings especially from field-grown stock plants are limited in their potential for mass propagation because of poor survival and rooting percentage, greenhouse space, labor, and stock maintenance. The high cost of production for micropropagation limits adoption of the technology for the Hawaiian industry. If costs can be lowered and offset by gains in yield and savings in planting, thinning, and maintenance, a clonally propagated plant cropping system could be adopted. Micropropagated plants maintained in the greenhouse for $>2$ months form tall stems that are readily rooted as two to four $10-\mathrm{cm}$ cuttings per plant (T. Leong, personal communication), at least tripling the number of rooted hermaphrodites in about 4 to 6 weeks. A protocol combining micropropagation and rooted cuttings could be cost effective.

\section{Literature Cited}

Allan, P.1964. Papaws grown from cuttings. Farm. S. Afr. 39:35-40.

Allan, P. 1993. Propagation of 'Honey Gold' papayas by cuttings. Acta Hort. 370:99-102.

Chan, L.K. and C.K.H. Teo. 2002. Micropropagation of 'Eksotika', a Malaysian papaya cultivar and the field performance of the tissue culture derived clones. Acta Hort. 575:99-105.

Deputy, J.C., R. Ming, M. M. M. Fitch, R. Manshardt, and J.I. Stiles. 2002. Molecular markers for sex determination in papaya (Caricapapaya L.) Theor. Appl. Genet.106:107-111. 
Drew, R.A. 1988. Rapid clonal propagation of papaya in vitro from mature field-grown trees. HortScience 23:609-611.

Drew, R.A. and J.N. Vogler. 1993. Field evaluation of tissue-cultured papaw clones in Queensland. Austral. J. Expt. Agr. 33:475-479.

Ferreira, S.A., K.Y. Pitz, R. Manshardt, F. Zee, M. Fitch, and D. Gonsalves. 2002. Virus coat protein transgenic papaya provides practical control of papaya ringspot virus in Hawaii. Plant Dis. 86:101-105.

Fitch, M.M.M., P.H. Moore, T.C.W. Leong, L.A.Y Akashi, A.K.F. Yeh, S.A. White, A.S. Dela Cruz, L.T. Santo, S.A. Ferreira, and L.J. Poland. 2005.
Clonally propagated and seed-derived papaya orchards: I. Plant production and field growth. HortScience (in press).

Hawaii Papaya Industry Association. 2004. Up and upwards. HPIA Wireless 1:1.

How, K. 1978. Solar Radiation in Hawaii 1932-1975. Report R57. Division of Water and Land Development, Department of Land and Natural Resources, State of Hawaii. Honolulu. 99 pp.

Manshardt, R.M. 1998. 'UH Rainbow' papaya. Univ. Hawaii Coll. Trop. Agr. Hum. Resour. Germplasm G-1.

Murashige, T. and F. Skoog. 1962. A revised medium for rapid growth and bioassays with tobaccotissue cultures. Physiol. Plant. 15:473-497.

Statistix 7 for Windows. 2000. Analytical software. Support@statistix.com.

Storey, W.B. 1953. Genetics of papaya. J. Hered. 44:70-78.

U.S Department of Agriculture Soil Conservation Service. 1972. Soil survey of the Islands of Kauai, Oahu, Maui, Molokai, and Lanai. State of Hawaii.

U.S Department of Agriculture Soil Conservation Service. 1973. Soil survey of the Island of Hawaii. State of Hawaii.

USGS. 1996. Geologic map of Hawaii Island. Edward W. Wolfe and Jean Morris (comp.). Sheet \#2. 